\title{
Broad Ligament Lipoleiomyoma Masses Two curious cases masquerading as ovarian carcinomas
}

"Surekha Yadav, ${ }^{1}$ Barkha Maheswari, ${ }^{1}$ Nishant Sagar, ${ }^{1}$ Varuna Mallya, ${ }^{1}$ Nita Khurana, ${ }^{1}$ Sangeeta Gupta ${ }^{2}$

$$
\text { الأورام الشحمية العضلية في الرباط العريض للرحمثم }
$$

سوريكا ياداف، بركا ماهيسواري، نيشانت ساجار، فارونا ماليا، نيتا كورانا، سانجيتا جويتا

ABSTRACT: Lipoleiomyomas are an extremely rare form of uterine leiomyoma; moreover, the occurrence of this type of tumour on the broad ligament is even rarer. We report two cases of broad ligament lipoleiomyomas in 15- and 38-year-old female patients who presented to the Lok Nayak Jai Prakash Hospital in New Delhi, India, between 2016 and 2017. In both cases, the preoperative diagnosis was of a solid ovarian malignancy. Most broad ligament tumours are mistaken for ovarian masses as they are difficult to diagnose radiologically.

Keywords: Ovarian Neoplasms; Leiomyoma; Broad Ligament; Thyroid Hormones; Hypothyroidism; Case Report; India.

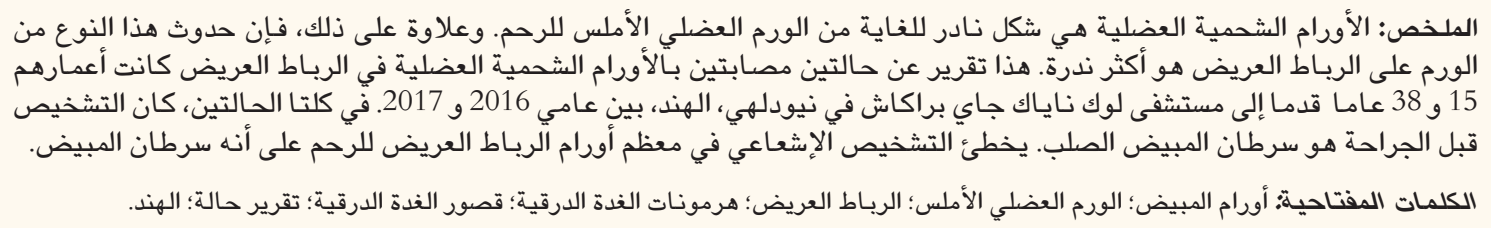

L IPOLEIOMYOMAS ACCOUNT FOR APPROXIMATELY $0.03-0.2 \%$ of all uterine leiomyomas and are comprised of a mixture of variable amounts of mature adipocytes and smooth muscle cells. ${ }^{1-3}$ Lipoleiomyomas typically occur in older post-menopausal women, whereas leiomyomas occur mostly in women of reproductive age and usually regress after menopause. ${ }^{2,3}$ The most common location of a lipoleiomyoma is the uterus, while other reported sites include the cervix, ovaries and, on occasion, the retroperitoneum..$^{2-4}$ However, lipoleiomyomas on the broad ligament-a peritoneal fold that connects the uterus to the pelvis-are extremely uncommon, with only seven cases reported in the literature to date.,.$^{2,5-10}$

Broad ligament lipoleiomyomas are difficult to diagnose preoperatively upon radiology and may be mistaken for an ovarian carcinoma. ${ }^{11}$ However, it is important to distinguish between these entities as broad ligament lipoleiomyomas can be treated conservatively with a lumpectomy. ${ }^{6}$ This report describes two cases of broad ligament lipoleiomyoma in which both patients were initially diagnosed with a solid malignant adnexal mass.

\section{Case One}

A 15-year-old girl was admitted to the Lok Nayak Jai Prakash Hospital (LNJPH), New Delhi, India, in 2016 with lower abdominal discomfort and an abdominal mass of three months' duration. The patient's past medical history was insignificant. She had first undergone menarche at the age of 12 years. A physical examination revealed a hard movable mass in the lower abdomen of a size similar to a pregnancy of 20 gestational weeks. There was no evidence of lymphadenopathy or organomegaly. Magnetic resonance imaging (MRI) showed a well-defined, large, solid, cystic abdominopelvic mass measuring 26 x 26 x $14.5 \mathrm{~cm}$. The mass was abutting the posterior wall of the urinary bladder, uterus, anterior wall of the rectum and the retroperitoneal structures, displacing the uterus and reaching up to the lower margin of the liver [Figure 1]. Laboratory tests revealed raised levels of serum thyroid-stimulating hormone $(14.74 \mu \mathrm{IU} / \mathrm{mL})$ and total triiodothyronine (T3; $60 \mathrm{ng} / \mathrm{dL})$, although her thyroxine $(5.42 \mu \mathrm{g} / \mathrm{dL})$ and free $\mathrm{T} 3(2.2 \mathrm{ng} / \mathrm{dL})$ levels were normal. Based on these clinical and radiological features, the patient was diagnosed with an ovarian tumour. 


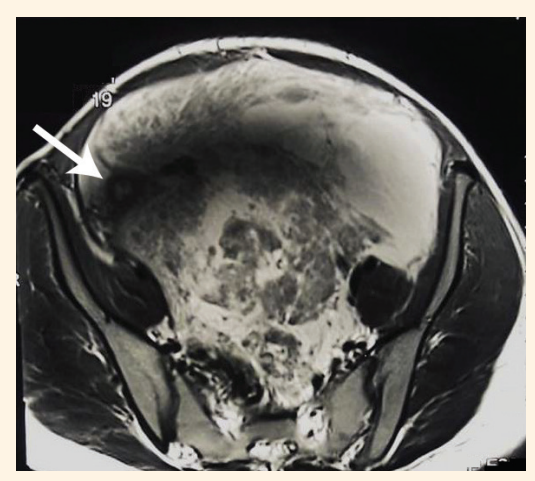

Figure 1: Magnetic resonance imaging scan of a 15-year-old female showing a heterogeneously enhancing solid-cystic pelvic mass (arrow).

An exploratory laparotomy revealed a tumour of $26 \mathrm{~cm}$ in size protruding out of the abdominal cavity. There was no connection between the tumour and the left ovary; instead, it was attached to the left lateral aspect of the uterus. Upon gross examination, the tumour was smooth, homogenous and greyish-white [Figure 2A]. The lump was excised and a specimen was sent for frozen section analysis. Microscopically, interlacing bundles of benign spindle-shaped cells with intermingled fat cells were observed [Figure 2B]. The randomly distributed fat cells were mature and there was no evidence of lipoblasts, mitosis, necrosis or angiomatosis. There was no cytological atypia in the spindle cells or adipocytes. On immunohistochemistry, the tumour cells were positive for smooth muscle actin (SMA) but negative for human melanoma black (HMB)-45. The patient was diagnosed with a broad ligament lipoleiomyoma and subsequently underwent conservative surgery to fully excise the mass. One week later, her thyroid hormone profile had returned to normal. At a six-month follow-up appointment, the patient appeared to be healthy with no evidence of disease recurrence.

\section{Case Two}

A 38-year old gravida 2, para 2 female presented to LNJPH in 2017 with an uncomfortable abdominal mass which had been increasing in size over the previous year. She had never experienced any menstrual irregularities and there were no significant events in her past medical or surgical history. A physical examination revealed a left-sided abdominopelvic mass without evidence of lymphadenopathy or organomegaly. Routine tests, including serum tumour markers, were within normal limits. An MRI scan showed a large left-sided heterogeneously enhancing abdominopelvic mass with
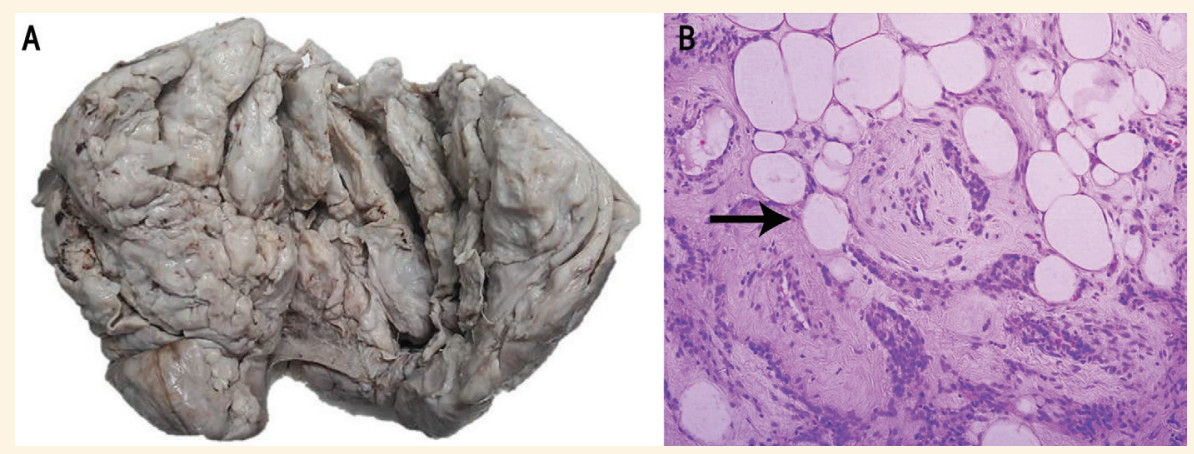

Figure 2: A: Gross image of an excised lesion from a 15-year-old female, showing a well-circumscribed greyish soft mass with a smooth external surface. B: Haematoxylin and eosin stain at x400 magnification showing mature smooth muscle cells and intermingled mature adipose tissue (arrow).
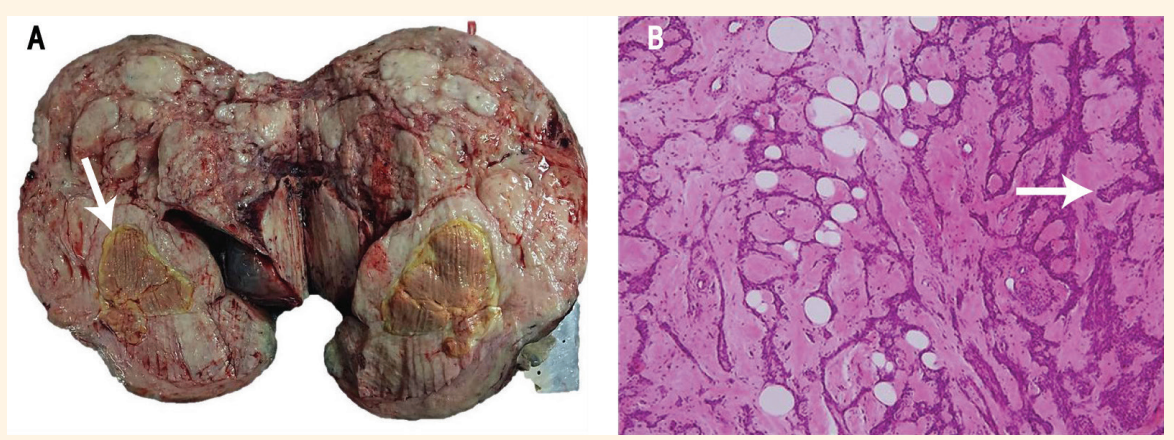

Figure 3: A: Gross photograph of an excised lesion from a 38-year old female, showing a homogenous greyish mass with focal areas of central fat (arrow). B: Haematoxylin and eosin stain at x400 magnification showing interlacing bundles of benign spindle-shaped cells with intermingled fat cells (arrow). 
Table 1: Literature review of cases of broad ligament lipoleiomyoma ${ }^{2,5-10}$

\begin{tabular}{|c|c|c|c|c|c|c|}
\hline $\begin{array}{l}\text { Author and year } \\
\text { of case report }\end{array}$ & $\begin{array}{l}\text { Patient age } \\
\text { in years }\end{array}$ & Symptoms & $\begin{array}{c}\text { Tumour } \\
\text { size in } \mathbf{c m}\end{array}$ & $\begin{array}{l}\text { Clinical } \\
\text { diagnosis }\end{array}$ & Treatment & $\begin{array}{l}\text { Associated } \\
\text { disease }\end{array}$ \\
\hline $\begin{array}{l}\text { Wang et al. }{ }^{2} \\
(2006)\end{array}$ & $54^{*}$ & - & $4.6^{*}$ & - & - & - \\
\hline $\begin{array}{l}\text { Mishra et al. }{ }^{5} \\
(2016)\end{array}$ & 45 & Abdominal pain & 17 & $\begin{array}{l}\text { Ovarian } \\
\text { tumour }\end{array}$ & TAH and BSO & None \\
\hline $\begin{array}{l}\text { Cinel et al. } \\
(2002)\end{array}$ & $\begin{array}{l}68 \\
54\end{array}$ & $\begin{array}{c}\text { Swelling } \\
\text { Abdominal pain }\end{array}$ & $\begin{array}{c}40 \\
8\end{array}$ & $\begin{array}{c}\text { Ovarian } \\
\text { neoplasm } \\
\text { Ovarian cyst }\end{array}$ & $\begin{array}{l}\text { TAH and BSO } \\
\text { TAH and BSO }\end{array}$ & $\begin{array}{l}\text { None } \\
\text { None }\end{array}$ \\
\hline $\begin{array}{l}\text { Kim et al. }{ }^{10} \\
(2012)\end{array}$ & 56 & Abdominal discomfort & 15 & $\begin{array}{l}\text { Mature cystic } \\
\text { teratoma }\end{array}$ & TAH and BSO & DM \\
\hline $\begin{array}{l}\text { Present cases } \\
(2017)\end{array}$ & $\begin{array}{l}15 \\
38\end{array}$ & $\begin{array}{l}\text { Abdominal discomfort } \\
\text { Abdominal discomfort }\end{array}$ & $\begin{array}{l}26 \\
30\end{array}$ & $\begin{array}{c}\text { Ovarian } \\
\text { tumour } \\
\text { Malignant } \\
\text { ovarian tumour }\end{array}$ & $\begin{array}{l}\text { Myomectomy } \\
\text { TAH and BSO }\end{array}$ & $\begin{array}{c}\text { Hypothyroidism } \\
\text { None }\end{array}$ \\
\hline
\end{tabular}

$T A H=$ total abdominal hysterectomy; BSO = bilateral salpingo-oophorectomy; $D M=$ diabetes mellitus.

*Mean.

lobulated margins measuring $30 \times 25 \times 15 \mathrm{~cm}$. The left adnexa was not visualised separately. A provisional diagnosis of a malignant ovarian tumour was made. Accordingly, the patient underwent a total abdominal hysterectomy with a bilateral salpingo-oophorectomy.

During the surgery, the tumour was observed to be separate from the left ovary and attached to the left broad ligament. There was no evidence of lymphadenopathy and all other organs appeared to be healthy. On gross examination, the tumour measured $30 \mathrm{~cm}$ in its greatest dimension and was homogenous and greyish-coloured, with focal yellow areas [Figure 3A]. Microscopically, the tumour showed features of a benign spindle cell lesion [Figure 3B]. Immunohistochemistry was once again positive for SMA but negative for HMB-45. The final diagnosis was of a broad ligament lipoleiomyoma. The patient appeared healthy at a three-month follow-up appointment.

\section{Discussion}

Lipomatous tumours of the uterus are divided into three groups: pure lipomas composed of mature adipose tissue, lipoleiomyomas composed of a mixture of smooth muscle cells and mature adipose tissue and malignant liposarcomas. ${ }^{2}$ The differential diagnosis of pelvic lipoleiomyomas includes both benign (i.e. teratomas, benign pelvic lipomas, non-teratomatous lipomatous ovarian tumours and lipoblastic lymph- adenopathy) and malignant (malignant teratoma and liposarcoma) lesions. ${ }^{6}$ A brief summary of reported cases of broad ligament lipoleiomyoma is shown in Table $1^{2,5-10}$ To the best of the authors' knowledge, the 15-year-old girl described in the first case of this report appears to be the youngest known patient to develop a broad ligament lipoleiomyoma.

Among lipoleiomyomas, distribution of the adipocytic component can vary widely from being uniformly spread throughout the tumour to a more focal concentration in small areas; as such, there is no defined cut-off percentage of adipocytes to confirm the diagnosis. In terms of appearance, those tumours containing few microscopic foci of adipocytes tend to resemble regular leiomyomas with large amounts of adipocytic components usually indicated by a yellowish appearance and a lobulated cut surface. ${ }^{2}$ Radiologically, the diagnosis of a lipoleiomyoma is challenging as these masses often resemble an ovarian tumour. ${ }^{9,11}$ The lobules of mature fat in a lipoleiomyoma intermingle with wisps of smooth muscles, which can be misleading and resemble the atypical hyperchromatic spindle cells of a well-differentiated liposarcoma. Therefore, the accurate diagnosis of this entity depends on the correct identification of the benign smooth muscle cells. ${ }^{7}$

Several hypotheses have been proposed to explain the origin of uterine lipoleiomyomas, including lipomatous metaplasia, metaplasia in the pluripotent 
mesenchymal cells or the perivascular extension of fat along the blood vessels with a complex histogenesis according to immunohistochemical studies. ${ }^{2,711}$ Renal angiomyolipoma-like vascular proliferation has also been reported in a case of lipoleiomyoma. ${ }^{5}$ However, neither of the present cases exhibited cellular atypia nor vascular proliferation; furthermore, the tumour cells were immunonegative for HMB-45. Patients with uterine lipoleiomyomas may also present with associated metabolic disorders like hyperlipidaemia, diabetes mellitus or hypothyroidism, like the younger patient described in this report. ${ }^{10-12}$ The cause of metabolic disturbances among older patients with lipoleiomyomas is generally assumed to be due to altered lipid metabolism; however, the precise reason for this alteration is still unknown. ${ }^{10}$

\section{Conclusion}

The diagnosis of a lipoleiomyoma can be challenging as their appearance upon imaging resembles that of a liposarcoma. Due to their solid nature, lipoleiomyomas may necessitate surgical intervention to relieve associated symptoms and rule out ovarian malignancy. Patients may also have underlying hormonal disturbances which normalise after surgery; as a result, regular follow-up appointments should be undertaken.

\section{References}

1. Prieto A, Crespo C, Pardo A, Docal I, Calzada J, Alonso P. Uterine lipoleiomyomas: US and CT findings. Abdom Imaging 2000; 25:655-7. doi: 10.1007/s002610000052.

2. Wang X, Kumar D, Seidman JD. Uterine lipoleiomyomas: A clinicopathologic study of 50 cases. Int J Gynecol Pathol 2006; 25:239-42. doi: 10.1097/01.pgp.0000192273.66931.29.

3. Aung $T$, Goto $M$, Nomoto $M$, Kitajima $S$, Douchi $T$, Yoshinaga $\mathrm{M}$, et al. Uterine lipoleiomyoma: A histopathological review of 17 cases. Pathol Int 2004; 54:751-8. doi: 10.1111/ j.1440-1827.2004.01748.x.

4. Mira JL. Lipoleiomyoma of the ovary: Report of a case and review of the English literature. Int J Gynecol Pathol 1991; 10:198-202. doi: 10.1097/00004347-199104000-00008.

5. Mishra SS, Saha A, Mishra P, Jena SK. Lipoleiomyoma of the left broad ligament with dermoid cyst in ipsilateral ovary and synchronous multiple benign lesions of female genital tract: An unusual association. Indian J Pathol Microbiol 2016; 59:355-8. doi: 10.4103/0377-4929.188117.

6. Bajaj P, Kumar G, Agarwal K. Lipoleiomyoma of broad ligament: A case report. Indian J Pathol Microbiol 2000; 43:457-8.

7. Cinel L, Düssmez D, Nabaei SH, Taner D, Pata O. Two intraligamentary lipomatous tumors with immunohistochemical features. Acta Obstet Gynecol Scand 2002; 81:786-7. doi: 10.1034/j.1600-0412.2002.810818.x.

8. Fernández FA, Val-Bernal F, Garijo-Ayensa F. Mixed lipomas of the uterus and the broad ligament. Appl Pathol 1989; 7:70-1.

9. Salman MC, Atak Z, Usubutun A, Yuce K. Lipoleiomyoma of broad ligament mimicking ovarian cancer in a postmenopausal patient: Case report and literature review. J Gynecol Oncol 2010; 21:62-4. doi: 10.3802/jgo.2010.21.1.62.

10. Kim HK, Kim JH, Hong SY, Choi YS, Oh HK, Lee TS. A uterine lipoleiomyoma of the broad ligament mimicking an ovarian tumor. Korean J Obstet Gynecol 2012; 55:787-90. doi: 10.5468/ KJOG.2012.55.10.787.

11. Aizenstein R, Wilbur AC, Aizenstein S. CT and MRI of uterine lipoleiomyoma. Gynecol Oncol 1990; 40:274-6. doi: 10.10 16/0090-8258(90)90291-R.

12. Lin KC, Sheu BC, Huang SC. Lipoleiomyoma of the uterus. Int J Gynaecol Obstet 1999; 67:47-9. doi: 10.1016/S0020-7292 (99)00094-6. 